Ana Došen

\author{
Faculty of Media and Communications \\ Singidunum University, Belgrade, Serbia \\ ana.dosen@fmk.edu.rs
}

\title{
Silent Bodies: Japanese taciturnity and image thinking*
}

\begin{abstract}
A nonverbal transmission and an implicit way of communication are highly encouraged in Japanese society. The reason for this "silence prerogative" is often found in historical facts of lengthy feudal era or in ancient philosophies and religions such as Buddhism and Confucianism and their various concepts which privilege taciturn way of communication. Moreover, the unspoken comprehension is often complemented by the attitude which equates truthfulness with silence. This paper explores the silence as a communicative act in the domain of Japanese art, where the body takes over the place of the language. In traditional Japanese theatrical performance, such as noh, words are often inadequate to convey emotion and therefore the aesthetics of emptiness, understatement and abstraction is transcended by the masks with "nonmoving lips". Drawing on theoretical perspectives from both East and West, I argue that the silent bodies operate as deliberate and integral determinants of Japanese non-silent art forms - especially in cinema and theatre. In the Eastern thought, visual perception is fundamental in cognition of the world, whereas auditory discernment is secondary to "image-thinking" (Yuasa). Accustomed to taciturnity, Japanese audience effectively corresponds to the performance and "completes" it in silence.
\end{abstract}

Key words: silence, Japan, ishin - denshin, haragei, enryo-sasshi, cinema, theatre, muga, ma, honne-tatemae

I: Certainly-because the one thing that matters is whether this dialogue, be it written or spoken or neither, remains constantly coming.

$J$ : The course of such a dialogue would have a character all its own, with more silence than talk.

I: Who could simply be silent of silence?

$J$ : That would be authentic saying...

I: ... and would remain the constant prologue to the authentic dialogue of language

I: Above all, silence about silence...

$J$ : Because to talk and write about silence is what produces the most obnoxious chatter...

Martin Heidegger, A Dialogue on Language between Japanese and an Inquirer

* This work is an expanded and revised version of the paper presented at the International Embodiments Conference - Silence: A Semiotics of (in)Significance, organized by University of Liverpool, UK in 2015. 
Our view of man will remain superficial so long as we fail to go back to that origin, so long as we fail to find, beneath the chatter of words, the primordial silence, and so long as we do not describe the action which breaks the silence.

The spoken word is a gesture, and it's meaning the world.

Maurice Merleau-Ponty, Phenomenology of Perception

Following two quotations above, writing about silence appears to be unappealing yet mandatory task. Overly repeated, John Cage's assumption that "there is no such thing as silence" has almost been canonized and continues to echo in the Western discourses. On the other hand, Michel Foucault's archeology and plurality of silence have been equally prominent. In order to explore the notion of silence in the context of Japanese cinema and theatre, I would focus on a topic of nonverbal transmission and an implicit way of communication existent in Japanese society. The aim of this paper is to suggest that enforced silence in the domain of Japanese film and performing arts evokes the intuitive reaction among the audience. Accustomed to taciturnity which is highly appreciated in Japanese culture, the spectators effectively correspond to the performance and "complete" it as a result of implemented silence. Without any intention of cultural essentialism, I argue that due to distinctive attributes and specificities of firmly established communicative practices in Japan, non-verbal expressions operate as significant aspects in perception of Japanese art. As regarding to methodology, constructivist and interdisciplinary approach of this paper devises from sources within and outside film and performance theory, including cultural anthropology, communication studies and linguistics.

\section{Anatomy of silence}

Although there are scholars who suggest that silence is a form of speech (Matarazzo, Hess, Saslow, Saville-Troike) and not its unambiguous opposition, it is possibly the most suitable reasoning not to offer a definitive inference when engaged with a subject of such intricate features. Nevertheless, its social and communicative dimensions remain undeniable, regardless of various approaches and perspectives.

When dealing with the employment and meaning of silence in Japanese culture, literature often examines the context of cross-cultural communication and (mis)understanding. Edward S. Hall's contribution to the field of intercultural communication is indisputable, as well as his influence on theorists interested in 
nonverbal communication in Japan (Ishii, Miike) ${ }^{1}$. In his book Beyond Culture (1976), Hall differentiates high and low context cultures, marking Japan's tendency towards high context messages in communication.

A high-context (HC) communication or message is one in which most of the information is either in the physical context or internalized in the person, while very little is in the coded, explicit, transmitted part of the message. (Hall 1976, 91)

This perspective allows us to acknowledge the prominence of the body itself in message conveying process. It can be also said that in high-context cultures spoken language exists only as a fragment of communication activity, and that its explicitness presuming definitive meanings is often referred to as an unwelcomed mode of transmission. Therefore, silence of the body enounces the meanings which could solely emerge beyond the reach of the words.

Various Japanese scholars pointed out the importance of silence as a feature of national expression. Toyama Shigehiko's concept of Japanese point logic resonates idea that intimacy does not need verbalization of the details (Befu 2001, 38), while Kindaichi Haruhiko embraces indirectness of the Japanese speaker and elliptical and concise speech. Proclaiming that Japanese arguments can only seem illogical due to a lack of its' explicit premises, logician Oide Akira also maintains the attitude of commemorating silence ( ibid). In general, for the Japanese, the public discussion indicates certain "thrusting one's opinion upon audience" (Prasol 2010, 71).

Many Japanese proverbs such as kuchi wa wazawai no moto (the mouth is the origin of disasters), iwanu ga hana (not saying is the flower), kiji mo nakazuba utaremai (the pheasant would not be caught but for its cries), naku neko nezumi torazu (a mewing cat will not catch a mouse) indicate the social and political threat of loquacity and the encouragement of silence. Tsujimura Akira finds the reasons for this "silence prerogative" in the historical fact that the Japanese "subjected themselves to restraint during a long feudal era and to the regulation of speech under totalitarian regimes" (Tsujimura 1987, 120). Tsujimura's perspective could only be taken partially, in the light of the other totalitarian societies which didn't develop the understanding that emerged from silence and taciturnity. This silent comprehension, quite common among the Japanese is complemented by the attitude which equates truthfulness with silence. Considering uchi - soto (inner-outer) dichotomy of Japanese communication system which is reflected directly in the Japanese language (honorific language - keigo differentiating respectful, polite and humble form), and is also a primordial part

${ }^{1}$ See more in Everett M. Rogers, William B. Hart, Yoshitaka Miike, "Edward T. Hall and The History of Intercultural Communication: The United States and Japan", Keio Communication Review 24, 2002. http://www.mediacom.keio.ac.jp/publication/ pdf2002/review24/2.pdf 
of a social apparatus, the verbal expression relates to a field of one's outer body while truthfulness, manifested in silence is located in inner realm (Maynard 1997, 154). Many of the concepts that privilege this way of communication are to be found in ancient philosophies and religions such as Buddhism, Confucianism and Taoism. Inadequacy of the language is transparent in Zen Buddhism where "true" communication is established through experience; Lankavatara Sutra diminishes the importance of both spoken and written words - "the truth is beyond the words", "words are not the highest reality, nor is what is expressed in the words the highest reality", "the attachment to words as having self-nature takes place owing to one's clinging to [...] false imaginings since beginningless time". In addition, the Confucian code of conduct loquacity of individual thoughts could lead to disharmony of the group. Also valuing collectivism, Taoist perspective prefers quietness of the non-interference along with enforcement of the interdependence.

Ishin - denshin has been the factor of the utmost importance in traditional Japanese culture. In Zen Buddhist tradition, this term outlines the communication between the master and his pupil toward the initiation of the truth. Also, in everyday terminology it marks an unspoken mutual understanding, which is considered to be more than telepathy. This concept recognizes the immediate transmission of thoughts, a mutual sensation for which the spoken words are unnecessary. Ishin-denshin is found in the story of disciple who accomplished the truth by faintly smiling while looking at Buddha admiring a white flower in his hand. The enlightenment wasn't prompted through listening to Buddha's preaching but through ordinary action of smiling. This intuitive, wordless communication is possible due to acquired experience and training.

Another Japanese concept that exempts silence is haragei which literally translates as "belly art". This corporeal notion assumes an implicit way of communicating, non-verbal mutual understanding and a "technique requiring sensitivity, experience and keen knowledge of others" (Maynard\&Maynard 1994, 111). Examining the significance of the silence, Takie S. Lebra notes that the Japanese

... believe that the truth lies only in the inner realm as symbolically located in the heart or belly. Components of the outer self, such as face, mouth, spoken words, are in contrast associated with cognitive and moral falsity. Truthfulness, sincerity, straightforwardness, or reliability are allied to reticence. Thus a man of few words is trusted more than a man of many words (Lebra 1987, 345).

Viscera are therefore marked as a center of intuition, instinct and real intention. Japanese saying - kuchi to hara ga hantai da (the mouth is the opposite of belly - one's real intention) and hara no naka de hidoku okoru (belly is the container of the emotion) prove that true emotions are not openly displayed and that close communication occurs through atmosphere of silence rather than the 
usage of words. Needless to say, silence is also integral part of the traditional form of ritual suicide - seppuku, when the abdominal cut categorically fractures the border between a true, instinctive inner realm and an outside world, terminating life in a wordless act.

Haragei is often related with another complex concept of Japanese communication pattern - amae which encourages nonverbal ambivalence and reluctance of self-expression. Famous Japanese psychoanalyst, Doi Takeo frames "the role of amae as an expectation that one's interlocutor can understand oneself without having to verbalize one's needs and feelings" (quoted in Miike 2003, 95). Doi's work on the subject of amae, especially his book The Anatomy of Dependence (1973) insists on this uniquely Japanese configuration of "indulgent dependency" entrenched in mother-child relationship which later forms other social relationships, has been almost compulsory for scholars interested in the field of Japanese interpersonal and intercultural communication. ${ }^{2}$ Amae operates as a corresponding relation between "concerned" and "dependent" communicator establishing idealized, mutual reliance. ${ }^{3}$ Further, it serves as a key to understanding Japanese culture in terms of highly valuated collectivism and group harmony which can be accomplished by, as suggested by Doi, subduing verbosity and activating another mechanism as a communicative strategy, that of enryo and sasshi.

Miike Yoshitaka's entry on enryo-sasshi theory in Encyclopedia of Identity vindicates the importance of nonverbal messages in Japanese social interaction. Naming Ishii Satoshi as a "Japanese pioneer in interpersonal and intercultural communication research" (Jackson II \& Hogg 2010, 250) who linked these two concepts ${ }^{4}$, Miike asserts that sasshi "demands that one should be very perceptive and receptive in order to understand what others mean or to sense of what others want or need" (ibid). I argue that this type of silent communication could find its ideal point of transference inside a film medium, spontaneously demanding of its audience to be sensitive, "guessing" the director's vision. Japanese film-making, born in the environment accustomed to such style of silent communication presupposes spectators' susceptibility to others' desideratum.

2 For further reading see Miike.

${ }^{3}$ Amae is a noun from intransitive verb amaeru - to depend on another's benevolence. It derives from the same root as adjective amai-sweet, forming a corealtion between "sweetening" and "being sweetened". Doi strenghtens nihonjinron discourse by asserting that such word does not exist in other languages (see more: Takeo Doi, "Amae: A Key Concept for Understanding Japanese Personality Structure" in Japanese Culture: Its Development and Characteristics, Robert John Smith and Richard King Besrdsley (eds.), London\& New York: Routledge, 2004, 134).

${ }^{4}$ Enryo refering to a restrain, not expressing true feelings in order to be considerate, and sasshi applying to a guess work capability to understand vague messages, a "mind reading". 
This type of understanding goes beyond semiotic film theory towards more personal, inner - "gut" comprehension, one that entails subtle relation between film director and his audience. Director's aesthetic relies on viewers' perceptiveness and competence to establish and conclude the message - his enryo activates the spectators' sasshi initiating a certain integrating process. Therefore, the collectiveness of Japanese national body could be seen not in terms of omnipresent unification and homogeneity but of insightful, supplemental communication practice. The magnitude of being "capable of accurately tuning into the faintest of signals" (Okabe 1983, 36) allows silence to be Japan's own style of expression, developing verbal moderation and anticipatory inference which implores the artistic vision to be recognized on a visceral level.

\section{Performing silence}

Sociolinguist Naruse Takeshi's assertion that "verbosity kills aesthetics; it is vulgar to say aloud what can be clear without words..."(quoted in Prasol 2010, 140) supports the attitude of desirable artistic use of silence.

In traditional Japanese theatrical performance, such as noh, words are often inadequate to convey emotion and therefore the aesthetics of emptiness, understatement and abstraction is transcended by the masks with "non-moving lips". Even the craftsmen who make the masks try to emanate neutrality of the facial expression, leaving the actor to convey the certain feeling with his body language. On the stage, in classical Japanese theatre - noh, bunraku, kabuki, the masks, the puppets or the make-up subvert the "ordinary" body into a presence born in the liminal space of the real and dreamlike state where the body emanates a divine manifestation that reveals to the audience a transgression of time and space.

In noh drama, the entire performance is devoted to emitting the $m a-$ an empty space, a gap, a pause, an interval or space between two movements or structural parts. This concept is inherent to other types of Japanese theater and different art forms - kabuki, butoh ${ }^{5}$, music, painting and calligraphy. An appreciation of traditional Japanese theatre does not derive from notion of mimesis as a mirror of reality, but through artist's ability to emanate the emotions with "formulaic and repetitive patterns of motion" even in the still performative occurrences in the setting of an empty space. "Concomitantly, both the practitioner

5 Judith Hamera in "Silence That Reflects: Buthoh, Ma, and a Crosscultural Gaze" argues that butoh favours the "extreme images of deformity and insanity" in order to depart from restrains of traditional forms of Japanese theatre. Moreover, Hamera's text offers an insightful understanding of notion of $m a$ as a "space between" which has been differently established and manifestated in noh and butoh. 
and the audience must feel engaged in the enactment of a particular embodied event." (Cavallero 2013, 71) This is particularly evident in noh which gives prominence to abstract, figurative expression instead of literal, and heavily relies on silence on stage. $M a$ serves as an aesthetic principal with an emphasis on a distance between two things. The balance between $m a$ and sound is most apparent in noh itcho - a recital followed by a single percussion instrument. "To the sensitive Japanese listener who appreciates this refined sound, the unique idea of $m a$ - the unsounded part of this experience - has at the same time a deep, powerful, and rich resonance that can stand up to the sound" (Takemitsu 1995, 51). One of the most influential Japanese architects Isozaki Arata and his exhibition "Ma: Space-Time in Japan" (1978-1981) shed the light on this concept to the Western audience.

To sense something invisible is an essence of Japanese art. [...] In painting, the focus has often been on the margin rather than on a shape, in music on silence rather than the notes and in dance on stillness rather than a movement. (Isozaki \& Oshima 2009, 158)

Hence, the invisible and inaudible have been intrinsic aspects of Japanese culture, notably allowing body thinking. Defining butoh seems to be complex task as its emanated contradictions (unpleasant-poetic, distant-erotic) leave spectators "compelled to verbal contortions to articulate what they see" (Baird 2012, 1). Founded by Hijikata Tatsumi as a performance art which represents and simultaneously challenges traditional Japanese aesthetics and the body, $b u$ toh frequently employs silent scream trope on the stage. In Pensée du corps La philosphie à l'epreuve des arts gestuels japonais (dance, théâtre, arts martiaux) (2012), Basil Dogains compares butoh dancer to a puppet:

If the body, in its most primary manifestation and its mere existence, presents more intensity and depth than a conscious artistic intention, then we would have to seek the minimal degree of intention of a particularity, of a personal will. However, since a part of consciousness and will always remains in action, the regulatory ideal will consist in "being dead" while being alive or, at least, in giving to the body some properties based on pure inertia. For Hijikata in butoh, as we saw, the will to dance always includes surprising desire of dispossession and handicap. Handicap is like a limit where the body is silent and refuses any principle of will and control. The dancer chooses to progressively give up all his ordinary capacities so as to become only an instrument, a tool, a mere support through which an uncontrollable intensity acts. (Quoted in Lambert 2013, 62)

In the early years of his performance, Hijikata's influential work Forbidden Colors (Kinjiki) (1959) revolved around the dance performed either in complete silence or to a recorded track of mixed sounds of harmonica, moaning and heavy breathing. One of Hijikata's aims was to use the performing body as a means of rebellion against societal and cultural conventions, often inducing shock among 
the audience. The provoked reaction, in terms of observers' physical responses, enabled further continuation of the performance as Hijikata did not rely on fixed narratives. Thus, silent bodies of the performers and the spectators are engaged in the creative act.

For art lovers, it is that space between oneself while perceiving, and what is being perceived in the flow of time. This space is sensory because it determines how our senses are solicited and it is...'sensual' because of how our minds will respond to what is aesthetically being perceived or expressed by artists. (Quoted in Cavallaro 2013, 26)

This type of "silence" both temporal and spatial, invites audience to participate in the artistic act; to use its own experience (and the body) in a certain imaginative process which takes place on the blurred line between dream and reality. Therefore, it is an aesthetic attribution which allows the multiplicity of perceptions. However, the purpose of this attribution of silence is only to mark the comprehension of the artistic intention that surpasses the language and which operates at the intuitive, corporeal altitude.

\section{Reflecting silence}

Apart from acknowledging that cinema in Japan is an extension of stage and not of photography as it is in the West, Donald Richie claims that there was no influence of the noh drama on the Japanese cinematic medium. (Richie 1971, $\mathrm{xx}$ ) What seems to evade this type of conclusion is precisely the silent interdependence of director-audience relation. Keiko I. McDonald seminal work Japanese Classical Theatre in Film (1994) in detail explores the theatrical influences on Japanese cinema, many adaptations of famous Japanese plays to the screen and formal properties of traditional Japanese theatre engaged in stylistic aspects in filmmaking of notable directors.

During the early beginnings of film viewing, Japanese audience showed immense interest in mechanism of screen projection, which resulted in incorporating necessary explanation in the performance itself, similar to the practice of changing of scenography in front of the audience in kabuki. Another characteristic of classical theatre performance that cinema "borrowed" from was the active role of narrator exposed to the audience.

When dealing with the domain of Japanese cinema, silence functions as a communicative act, although, paradoxically, from the very beginning of the motion pictures showing in Japan (1896), cinema was never "silent". Namely, watching movies in theaters was always accompanied with the figure of benshi - a narrator or group of narrators "explaining" what was projected on a silver screen and whose role was "educational" as they enlightened the audience on 
matters of Western culture. ${ }^{6}$ The popularity of such "explainer" was greater in Japan than in other countries and the reason for this extreme influence and prestige is found in "Japanese enthusiasm for self-improvement" (Richie 1971, 6). Thus, full experience of moving pictures could not be achieved in silent era and benshi's role was fundamental, whereas today silence in sound films emphasizes the impact of the visual. Even though the first sound film appeared in 1926 (Reimai, Dawn), benshi impact has not faded away until mid 1930s, bringing the silence into the visual experience of the sound movies and leaving audience to intuitively complement the moving images.

Japanese understanding of experience differs from Western - it is rather culturally specific and "shared" than universal phenomenon. According to Nishida Kitaro's view, experience does not separate subject and object, nor is it material, individual and psychological but is viable as a domain of "intersubjective" meanings. ${ }^{7}$

Yuasa Yasuo's Overcoming Modernity - Synchronicity and Image-Thinking offers a perspective of mind-body integration as a philosophical foundation of thinking paradigm which integrates image-experience within it. The underlying principle of relation between self and world, Yuasa finds in visual expressions, in correlation from "seeing" to "seen" when "embodied subject (shutai) sees the world in the midst of silence" (Yuasa 2008, 78). Yuasa suggests the path of "overcoming modernity" 8 by rectifying the beliefs in superiority of human ratio that professes infinite progress, dominant in philosophical claims of Descartes and Kant. According to Yuasa, differences in Western phonetic and Eastern pictograph communicative systems prove the assumption of language impact on the ideas and philosophies of certain culture. Emphasis on grammatical rules and sentence structures in Western languages, leads to development of logic and ontology that East lacks.

In the Eastern thought, visual perception is fundamental in cognition of the world, whereas auditory discernment is secondary to "image-thinking". Self-ex-

${ }^{6}$ Along with benshi, there were also kowairo who imitated the the voices of the actors on the screen. I have further explored the role of benshi in "Bemusing the Audience: Probing the Narrative Diversions in Symbol", Ekphrasis 15 (1): 75-85, 2016.

7 For further reading: Andrew Feenberg, "The Problem of Modernity in the Philosophy Of Nishida", Rude Awakenings, J. Heising and J. Maralado (eds.), Honolulu: University of Hawaii Press, 1994.

8 "Kindai no chokoku" was famous symposium held in 1942 in Kyoto where prominent intellectuals gathered to discuss issues of Japan's identity, cultural originality and transformative changes which occurred in cultural and technological domains through process of modernization. Insisting on an authenticity and originality of Japan's culture, the participants rejected the idea of European exclusivity to define modernity for the entire world. 
pression through images is a crucial point in the Eastern realm where verbal linguistic expression renders as subordinate. In a wordless state, the body

is not a collection of particles, each one remaining in itself, nor yet a network of processes defined once and for all - it is not where it is or what it is - since we see it secreting in itself a 'significance' that comes to it from nowhere, projecting that significance on to its material surrounding, and communicating it to other embodied subjects. (Merleau-Ponty 2012, 229)

Yuasa strongly opposes Cartesian dualism which privileging cogito sets humans to observe the nature from the outside position, and offers "mind-body integration" instead. Logical thinking, deduction allows the strategy of exclusion, dividing the one (whole/being) in two parts. This separation has become a methodological tool when investigating all material phenomena. In Eastern worldview, human understanding of its environment emerges from intimate connection between them, and with no inclinations towards the knowledge that provides power and control over the nature. This Eastern inseparability of mind and body enables considerable spontaneity of reaction, greater than the one which has to go through immediate process of "reunification" of the distinguished traits of human being which Western perspective proclaims. Even in the environment of such recognized integration, the Eastern theories observe the change in mind-body unity that occurs through the different sets of practices and training.

Given that Eastern philosophies do not recognize mind-body divide, it is appropriate to employ Gilles Deleuze's "natural history of cinema" which determines the movement-image and the time-image. His theory of moving images overcomes Cartesian concept of res cogitans and res extensa, for it suggests that in cinema both mind and body are united in inseparable whole.

For Deleuze, [however,] the time-image cinema does not abandon the body. Indeed, it is in the moments that the body is freed to its own gestures that perception is freed from the usual round of action, enabling us to think anew. "Not that the body thinks, but, obstinate and stubborn, it forces us to think, and forces us to think what is concealed from thought, life" $(1989,189)$. A certain kind of time-image, then, is both experienced in the body and invites a direct experience of time. [..] These are not simple acts of displacement: they also reveal knowledge that has been stored only in the memory of the body. When the verbal and visual archives are silent, information is revealed that was never verbal or visual to begin with. (Marks 2000, 74,76)

On the other hand, the movement-image provokes perceptions and actions in the human body, as such in the case of action scenes which depict sensory-motor movement.

Aesthetic concept yugen ( $y u$ - shadow-filled, gen - darkness) refers to something mysterious, concealed too deep to be visible and comprehended. Through 
cinematic images, yugen as "the ideal of an artistic effect both mysterious and ineffable, of a subtle, complex tone achieved by emphasizing the unspoken connotations of words" (quoted in Richie 2007, 31) is invoked in the bodies of Japanese spectators. Yugen is recognized in the body movements and unvoiced attitudes of the actors, but also as a concept that "means what lies beneath the surface" (ibid.), it is deeply connected to the visceroceptiveness ${ }^{9}$ of the spectators. Nurturing the values of the implicit, yet visually potent communication, Japanese aesthetics establishes the more delicate responsiveness of the perceivers.

This noticeable dissonance of "silence appreciation" between Japan and the West can be traced in Adachi Reito's informative text "Dubbing of silences in Hayao Miyazaki's Spirited Away: A comparison of Japanese and English language versions". Adachi points out that in general, Japanese animated movies have significantly more silences per 10 minutes that US animated films, and that the US translation of anime considerably tends to avoid silences of the original. Putting aside the variables of the dialogue styles in Japanese and English, Adachi claims that Japanese silences are reduced, along with narrative taboos - such as sexuality and violence ${ }^{10}$, for "the purpose of explicitness, domestication, and avoidance of awkwardness" (Adachi 2016, 146). Interestingly, the US dubbing enforces "acoustic adaptations to a greater extent than linguistic modifications to fill the silences in the original Japanese version" (Adachi 2016, 149). Therefore, localizing silence and its use in the art forms reveals the possible communicative glitches which are usually neglected when encountering the foreign cultures.

In addition to aforementioned notions of taciturnity and body thinking, muga is another Japanese concept that translates as "selflessness" which is achieved through a "thoughtless" practice and coordination of physical movements that lead to mastery of one's skill. It is recognized among different professions samurai, artists, musicians, sportsmen etc., Boye Lafayette De Mente recognizes muga in the artistry of spontaneous movements, made possible through a long process of training. Statement which explains muga as "a state in which the mind did not interfere with the actions of their trained bodies" 11 presumes

9 This phenomenon was further explored by author in "Viscerocepcija: (japansko) telo koje misli i umetnost", Art+Media, Vol. 11 (to be published).

${ }^{10}$ Adachi refers to the following avoidance in US version of Miyazaki's Oscarwinning anime fantasy - Spirited Away: the expression "torn from limb to limb", which resulted in extension of the dialogue for several seconds, and a "dramatic silence" of the scene in which a character finds himself in the dark and desolated backstreets which was modified with added voices and noise in the background, in order to spare US audience of feeling "uncomfortable" and thus, diminishing the director's intended vision of intense atmosphere and suspense.

11 Boye Lafayette De Mente, "MUGA: A Japanese Word You Should Know" http:// boyelafayettedemente.blogspot.rs/2007/03/muga-moo-gah-japanese-word-you-should.html 
silence. Though quietness, trained bodies of Japanese spectatorship establish muga by movements of their inner organs.

In Japanese society double codes of behavior are being used: honne - true feelings, the real self and tatemae - facade, a public face. Despite this type of conduct being common in other cultures as well, the Japanese insist on this divide as a national trait which often results in foreign misunderstanding of the Japanese and their labeling as "hypocritical". From Japanese perspective, their displayed behavior which foreigners consider as reservedness, deceit or cold attitude - is misinterpreted due to foreign lack of understanding of tatemae concept. "What Lebra calls the 'cultural pressure for situational discrimination' (1976:136) is embedded in the intricacy of social roles and positions, and the metaphor of hara is located within such Japanese social milieu." (Matsuki 1995, 144)

Accustomed to appreciate and foster keeping their true sentiments hidden, in order to maintain group harmony ( $w a$ ), Japanese visceral activity is rather considerable. Suppressed by enforced tatemae, in "silent" public and collective film viewing, contained emotions, feelings and intuition affect the insides and depths of spectators' bodies. Unnoticeable visceral reaction, the secretive movements intensified by moving images do not disrupt collective harmony. Noting that Japanese directors come from the same culture of restrained expressiveness of emotions and dynamic inner-body activities, their methodological and aesthetic use of the on-screen bodies, often in extreme, violent conditions (particularly noticeable in the work of Miike Takashi and wide range of anime) provokes dramatic, intimate experience in the viewers. Flesh of the screen engages the viewers' viscera, drawing the attention to the invisible textures and patterns of Japan's body. The uncertain, apocryphal features of honne complement unpredictable visceral responses.

We can also draw a connection between this social categorization, tatemae-honne, and cinematic taxonomy related to Japan which Donald Richie mentions. Tatemae refers to idealization, as what should be said (or left unsaid) and displayed in front of others (outsiders). Among foreigners, it is required to be imposed "before important people who must be impressed or lesser beings who do not have access to the inside dope" (Woronoff 1990, 17). Turning to the insights of directors Kawashima Yuzo and Imamura Shohei, Richie points out to "official-real" opposition of Japan's displayed characteristics. Namely, what is generally intended to be shown is an official version of Japan - "noh, tea ceremony, Mizoguchi, Ozu, late Kurosawa, along with the approval high-class virtues of fidelity and devotion" (Richie 2005, 184). On the other hand, real Japan, depicted in the films of previously mentioned directors such as Kawashima and Imamura, was full of ignored lower class which was anything but refined and subtle. Those films could be considered as rude and improper honne of Japanese cinema. 
In a culture with a long tradition of acknowledged mind-body unity, and as a being-inside-the-world, one's image experience can only be intuitively apprehended. As stated in this paper, silence is an intermediary agent in corporeal production of meanings, also affirming the notion of Japanese aesthetics that more values suggestive over the explicit. Drawing on theoretical perspectives from both East and West, it seems justifiable to suggest that the silent bodies operate as deliberate and integral determinants of Japanese non-silent art forms - especially in cinema and theatrical performances. In a culture which highly values taciturnity, silence is a significant aspect of the performance as it provokes the audience to complement the perceived work of art.

\section{References}

Adachi, Reito. 2016. Dubbing of silences in Hayao Miyazaki's Spirited Away: A comparison of Japanese and English language versions. Perspectives: Studies in Translatology 24 (1): 142-156.

Baird, Bruce. 2012. Hijikata Tatsumi and Butoh - Dancing in a Pool of Gray Grits. New York: Palgrave Macmillan.

Befu, Harumi. 2001. Hegemony of Homogeneity. Melbourne: Trans Pacific Press.

Cage, John. 1973. “45' for a Speaker”. In Silence: Lectures and Writings by John Cage. Hanover: Wesleyan.

Cavallero, Dani. 2013. Japanese Aesthetics and Anime, Jefferson. NC \& London: McFarland \& Company.

Deleuze, Gilles. 1997. Cinema 1-The Movement-Image. University of Minnesota Press.

De Mente, Boye Lafayette. MUGA: A Japanese Word You Should Know. http://boyelafayettedemente.blogspot.rs/2007/03/muga-moo-gah-japanese-word-you-should.html

Dosen, Ana. 2016. Bemusing the Audience: Probing the Narrative Diversions in Symbol. Ekphrasis 15 (1): 75-85.

Došen, Ana. Viscerocepcija: (japansko) telo koje misli i umetnost. Art+Media 11 (to be published).

Hall, Edward T. 1976. Beyond Culture. New York: Anchor Books.

Hamera, Judith. 1990. Silence That Reflects: Buthoh, Ma, and a Crosscultural Gaze. Text and Performance Quarterly 10 (1): 53-60.

Isozaki, Arata and Ken Tadashi Oshima. 2009. Arata Isozaki. London: Phaidon Press. Kindaichi, Haruhiko. 2010. The Japanese Language. Tokyo: Tuttle Publishing.

Jackson II, Ronald L. And Michael A. Hogg (eds.). 2010. Encyclopedia of Identity. Vol.I, SAGE Publications.

Lambert, Leopold (ed.). 2013. The Funambulist Pamphlets: Spinoza. New York: Punctum Books.

Lebra, Takie S. 1987. The cultural significance of silence in Japanese communication. Multilingua 6-4: 345-357.

Marks, Laura U. 2000. The Skin of the Film. Durham and London: Duke University Press. 
Matarazzo J. D, H.F. Hess, G. Saslow. 1961. Frequency and duration characteristics of speech and silence behavior during interviews. Journal of Clinical Psychology 18 (4): 416-426.

Matsuki, Keiko. 1995. "Metaphors of anger in Japanese". In Language and the Cognitive Construal of the World, eds. John R. Taylor and Robert E. MacLaury, 137-152. Berlin \& New York: Mouton de Gruyter.

Maynard, Michael L. and Senko K. Maynard. 1994. 101 Japanese idioms: Understanding Japanese Language and Culture Through Popular Phrases. Lincolnwood, IL: Passport Books.

Maynard, Seneko K. 1997. Japanese Communication: Language and Thought in Context. Honolulu: University of Hawaii Press.

McDonald, Keiko I. 1994. Japanese Classical Theater in Films. London \& Toronto: Fairleigh Dickinson University Press.

Merleau-Ponty, Maurice. 2012. Phenomenology of Perception. London \& NewYork: Routledge.

Miike, Yoshitaka. 2003. Japanese Enryo-Sasshi Communication and Psychology of Amae: Reconsideration and Reconceptualization. Keio Communication Review 25: 93-115.

Nishida, Kitaro. 1992. An Inquiry Into the Good. Yale Univesity Press.

Okabe, Ryoichi. 1983. "Cultural assumptions East and West: Japan and the United States". Intercultural communication theory: Current perspectives, ed. W. Gudykunst, 22-41. Beverly Hills, CA: Sage Publications.

Prasol, Alexander. 2010. Modern Japan: Origins of the Mind. Hackensack, NJ \& London: World Scientific Publishing Co.

Richie, Donald. 1971. Japanese Cinema - Film Style and National Character. New York: Anchor Books.

- 2005. Hundred Years Japanese Cinema. Tokyo: Kodansha.

- 2007. A Tractate on Japanese Aesthetics. Stone Bridge Press.

Suzuki, Daisetz Teitaro (trans.). 2009. Lankavatara Sutra: A Mahayana Text. Motilal Banarsidass.

Takemitsu, Toru. 1995. Confronting Silence - Selected Writings, Lanham, Maryland: The Scarecrow Press, Inc.

Tanen, Deborah and Muriel Saville-Troike (eds.). 1985. Perspectives on Silence. Norwood, NJ: Ablex Publishing Corporation.

Tsujimura, Akira. 1987. "Some Characteristics of the Japanese Way of Communication." Communication Theory - Eastern and Western Perspectives. ed. D. Lawrence Kincaid, 115-126. San Diego: Academic Press, INC.

Yuasa, Yasuo. 2008. Overcoming Modernity - Synchonicity and Image-Thinking. New York: State University of New York Press.

Woronoff, Jon. 1990. Japan As Anything But Number One. Amornk, NY: M.E.Sharpe. 
Ana Došen

Fakultet za medije i komunikacije, Univerzitet Singidunum

Beograd, Srbija

Tela u tišini: japanska uzdržanost i "mišljenje slika"

Neverbalna transmisija i implicitan vid komunikacije su izrazito zastupljeni u japanskom društvu. Razlog za pomenuti "prerogativ tišine" se često pronalazi u istorijskim uslovljenostima dugim periodom feudalizma ili filozofskim i religijskim doktrinama poput budizma i konfučijanizma koji favorizuju "zadršku" u direktnoj komunikaciji. Pored toga, razumevanje koje se postiže kroz neizgovoreno, praćeno je stanovištem koje izjednačava tišinu i istinu. Ovaj rad preispituje tišinu kao komunikacijski čin u domenu japanske umetnosti, u kojoj telo preuzima mesto jezika. U tradicionalnim formama japanskog teatarskog izvođenja, poput No-drame, reči su obično neadekvatne za prenošenje emocija, te se estetika praznine, nagoveštaj i apstrakcija otelotvorava putem maski sa nepomičnim ustima. Oslanjajući se na teoretske pretpostavke Istoka i Zapada, zastupam stanovište da "tela u tišini" funkcionišu kao sastavni elementi japanskih umetničkih formi, poslebno filma i pozorišta. U istočnim filozofijama, vizuelna percepcija je od suštinske važnosti za razumevanje sveta, dok je zvučna komunikacija sekundarna u odnosu na "mišljenju slika" (Yuasa). Naviknuta na rezervisanost, japanska publika efektivno korespondira sa izvođenjem/delom i "dovršava" ga u tišini.

Ključne reči: tišina, Japan, ishin - denshin, haragei, enryo-sasshi, film, pozorište, muga, ma, honne-tatemae

Des corps dans le silence: la retenue japonaise et la "pensée des images »

La transmission non-verbale et la forme implicite de communication sont extrêmement présentes dans la société japonaise. La «prérogative du silence» évoquée est souvent expliquée par les circonstances historiques, plus précisément par une longue période de régime féodal ou bien par des doctrines philosophiques et religieuses comme le bouddhisme et le confucianisme qui favorisent la «retenue» dans la communication directe. Par ailleurs, la compréhension acquise à travers le non-dit, fait naître l'optique qui égalise le silence et la vérité. Ce travail s'interroge sur le silence comme acte de communication dans le domaine de l'art japonais, dans lequel le corps prend la place de la langue. Dans les formes traditionnelles de performance théâtrale japonaise, à l'instar du No-drame, les mots sont généralement non-adéquats pour la transmission des émotions, ce pourquoi l'esthétique du vide, de la suggestion et de l'abstraction s'incarne par le biais des masques avec des bouches immobiles. En prenant ap- 
pui sur les supposés théoriques de l'Orient et de l'Occident, j'affirme que «les corps dans le silence» fonctionnent comme des éléments constitutifs des formes artistiques japonaises, notamment du film et du théâtre. Dans les philosophies orientales, la perception visuelle est d'une importance capitale pour la compréhension du monde, alors que la communication acoustique est secondaire par rapport à la " pensée des images » (Yuasa). Habitué à la retenue, le public japonais communique effectivement avec la performance/l'œuvre et la «termine» dans le silence.

Mots clés: silence, Japon, ishin - denshin, haragei, enryo-sasshi, film, théâtre, muga, ma, honne-tatemae

Primljeno / Received: 4. 09. 2016.

Prihvaćeno / Accepted: 23. 11. 2016. 